\title{
SIGNIFICANCE OF RESINOUS TRACHEIDS
}

\author{
SAMUEL J. RECORD
}

(WITH FIVE FIGURES)

The occurrence of resinous tracheids in gymnosperms has been noted by PENHALLOW ${ }^{\mathrm{T}}$ in the woods of certain species of Cordaites, Araucaria, Dammara, and a few representatives of the higher Coniferales, namely, Pinus albicaulis, P. parviflora, Abies Fraseri, and $A$. grandis. Such tracheids do not differ structurally from other tracheids, but are distinguished by their resinous contents. The resin within them is localized and usually extends across the cavity to form an imperforate septum or plate, which, in unstained sections, may give the cell the appearance of being structurally septate.

Penhallow figures the common form of these plates in Dammara australis. Figs. $\mathrm{I}^{-3} 3$ illustrate the resinous tracheids in the wood of Pinus albicaulis, showing the characteristic form of the resin masses $(R P l)$ and their association with the medullary rays. The resinous contents of the latter are omitted in order not to obscure the structure. It will be noted that there is considerable difference in the thickness of these plates, which are invariably thinnest in the middle, and not infrequently ruptured there. By comparison with Penhallow's drawings it will be seen that the location, form, and distribution of the resin masses in the two species are identical.

The close association of the rays with the resin plates in the tracheids clearly indicates the origin of the resin, which in some cases can be seen in the form of globules on the outside of the pit membrane of the parenchyma cell. When enough has exuded to form contact with the opposite wall of the tracheid, the surface tension of the liquid and the attraction of the cell wall cause it to assume a double concave form like a drop of water in a small glass

${ }^{I}$ Penhallow, D. P., A Manual of the North American gymnosperms. Boston: Ginn \& Co. 1907 (pp. 53-58). 
tube. Sometimes there is enough resin to fill the tracheid for a considerable portion of its length, at others only enough to produce very delicate plates, while in the case of a cell with a wide lumen the resin may run down along one side or collect in masses without connection across the cavity. It is not unlikely that the presence of gas bubbles in the cells at this stage may play a part in forming the plates and in determining their location, since in some instances

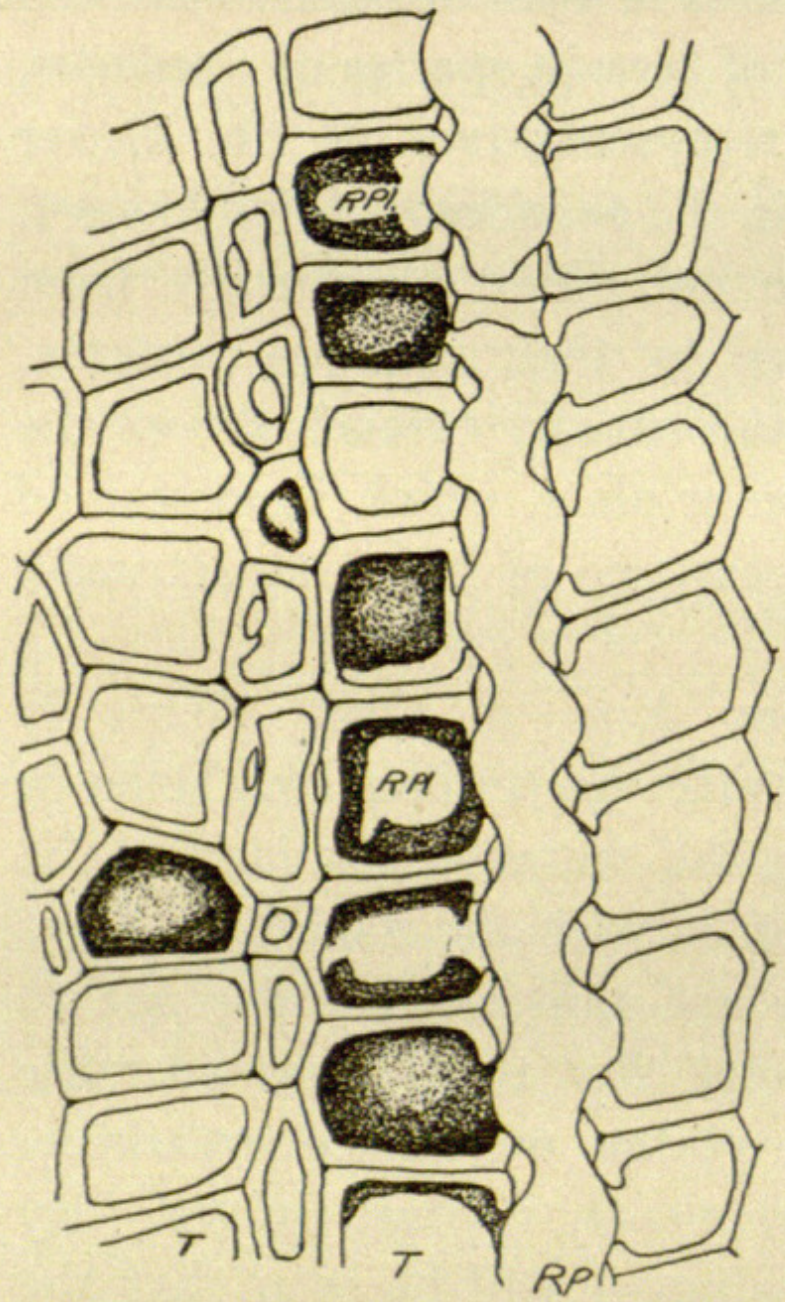

Fig. I.-Transverse section of Pinus albicaulis.

a thin plate may be found at a considerable distance from the ray and without visible connection with it.

What is the significance of these plates? Penhallow says as follows:

The peculiar form in which the resin is deposited and the particular location of the plates point with much force to their connection with some functional activity, since if it were simply a question of the storage of secreted products, the latter would hardly be disposed as found, but rather after the manner common to so many of the Cupressineae; and this suggestion gains strength from the fact that with respect to the peculiar form of the resin masses as well as their location in the tissue, the Cordaitales are peculiar among the gymnosperms. No exact comparison can be established with other plants, and it is difficult to suggest an adequate explanation. One thing does seem clear, however, and that is that since these plates are of an impervious nature and developed in some cases, at least, in connection with a special constriction of the tracheid cavity, they offer and possibly are specially designed to afford a definite obstruction to circulation in a vertical direction. In this sense they may be designed to serve the same general purpose that is accomplished by the development of tyloses in the vessels of the angiosperms or in the resin passages of the higher Coniferales. It is possible, therefore, that they may be connected in some way, not at present clear, with a more complete restriction of the circulation to a horizontal direction, and particularly through the medium of the medullary rays as specialized channels for that purpose. Among existing 
gymnosperms resinous tracheids are almost exclusively confined to Dammara and Araucaria, though it is a noteworthy fact that similar structures occur rarely among the higher Coniferales..... The taxonomic value of the

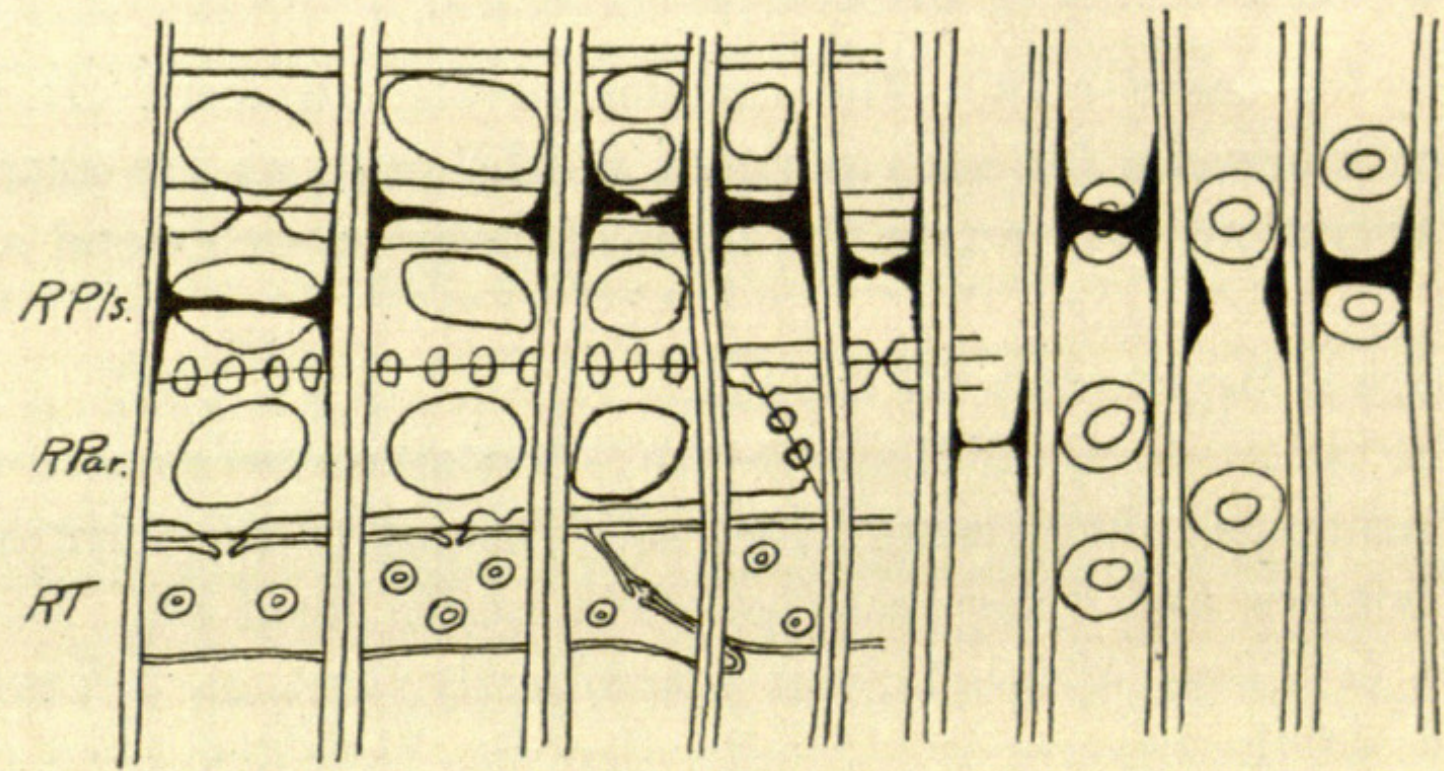

FIG. 2

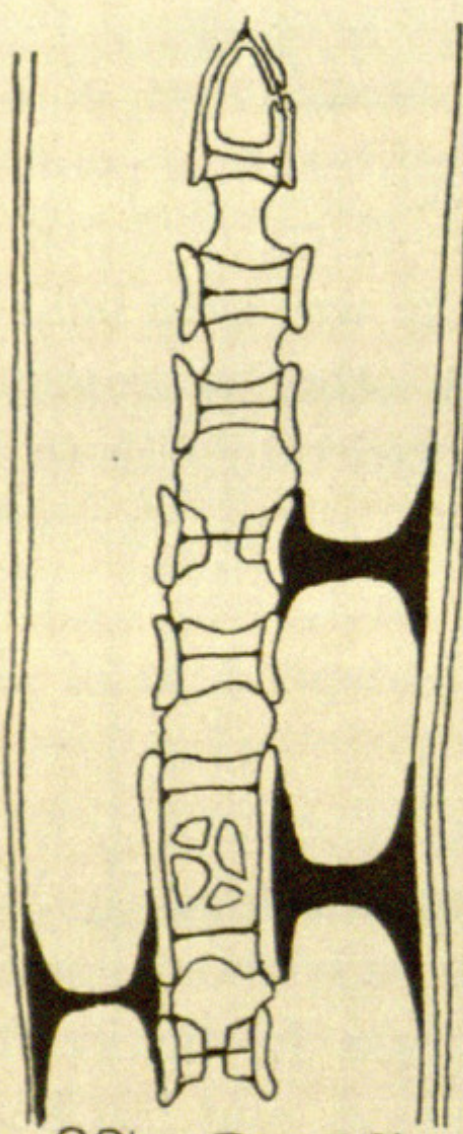

RPI. R RP/s

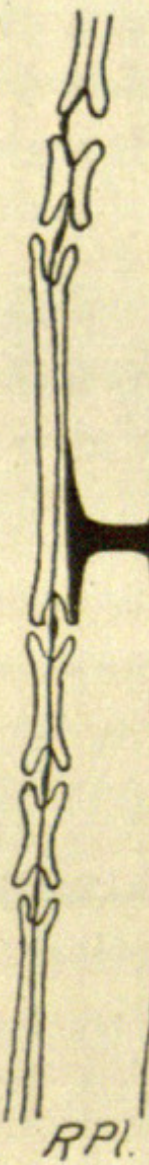

PPI.

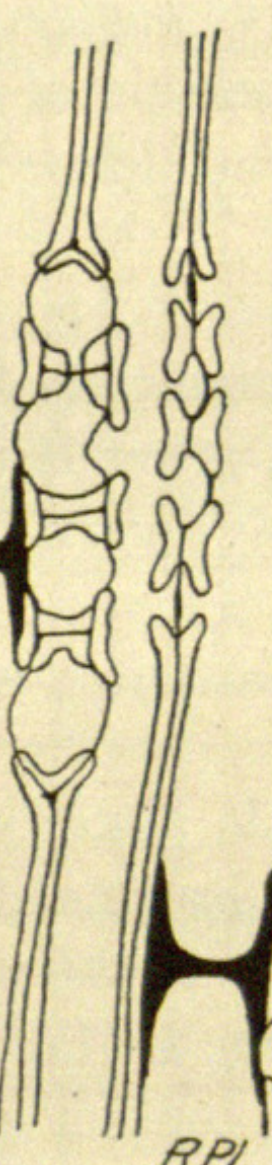

PPI $R$

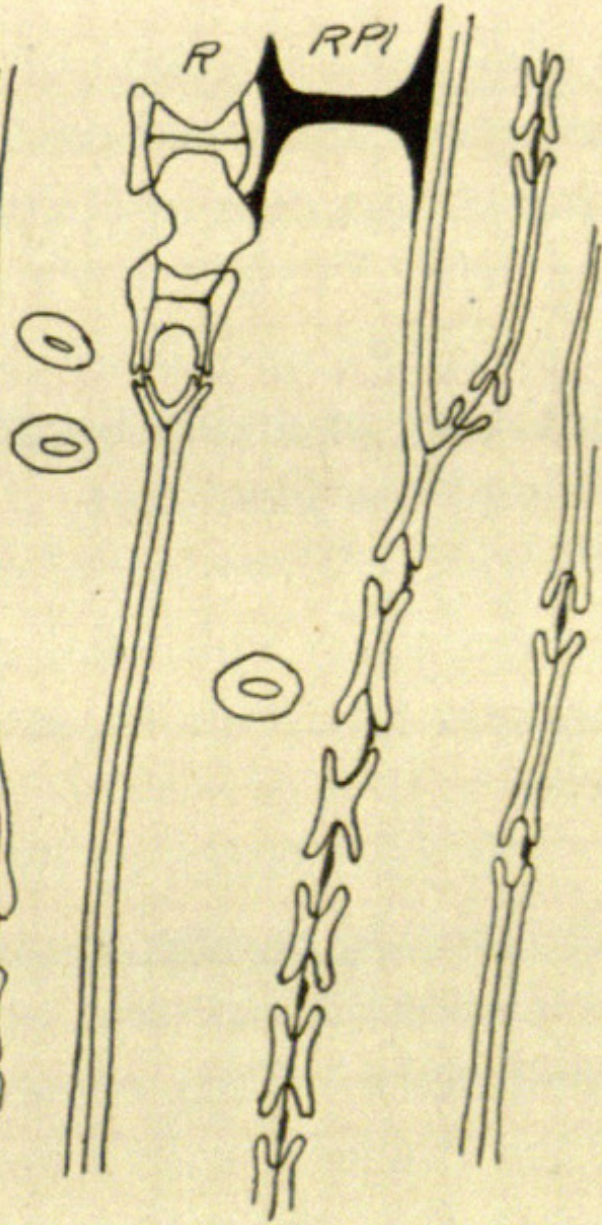

Fig. 3

FIgs. 2, 3.-Fig. 2, radial section; fig. 3, tangential section of Pinus albicaulis

resinous tracheids applies exclusively to the Cordaitales, where they are of ordinal value, though in Dammara and Araucaria they may also become of specific value. 
The "peculiar form" and the "particular location," upon which Penhallow laid special stress, are readily understood when their origin is appreciated. The resin is produced in the parenchyma as a product, or more likely as a by-product, of the metabolic activity of those cells. The cavities of the adjacent tracheids become reservoirs for such portions of the resin as are excreted. Such excretions may retain the form of globules, or extend across the cavity and assume the form of thick or thin plates, or when the quantity is large nearly fill the cell.

The writer does not consider the "Cordaitales". (Araucarians) peculiar among the gymnosperms with respect to the form of the resin masses and their location. The same form and location obtain in Pinus albicaulis, not sporadically, but as a constant feature of the heartwood. Similar deposits have also been noted occasionally in the tracheids of $P$. resinosa, Picea sitchensis, and in abnormal sapwood of Pinus ponderosa, while globules of resin have been observed on the outside of the pit membranes of ray parenchyma cells in P. Strobus. These instances, taken in connection with Penhallow's note of the occurrence of resin plates in $P$. parviflora and in two species of Abies, lead the writer to believe that they probably occur sporadically in many other representatives of the Coniferae. The writer has also noted tracheids in $P$. albicaulis with resin globules at several lateral pits connecting with the secondary epithelial cells of a vertical resin duct, showing that resinous tracheids in some instances may be independent of the rays.

The association of the resin plates with special constriction of the tracheid cavity, as noted by PenHallow and figured by him for Dammara australis, appears to the writer to be without special significance. This constriction is due to increase in thickening of the tracheid walls where in contact with the rays, and has been observed by the writer as a common feature of the woods of various genera of the Coniferae, especially in the thick-walled cells formed late in the season. Such increase is presumably due to greater nutrition at that portion, and in most species is not in connection with resin plates, while the resin masses also occur where there are no such constrictions. 
Penhallow states that no exact comparison can be established with other plants. The writer believes that exact parallels exist in many of the angiosperms. A good example is Nyssa sylvatica, and figs. 4 and 5 show resin-like plates $(R P l)$ in this wood which exhibit virtually the same origin, form, and distribution as those

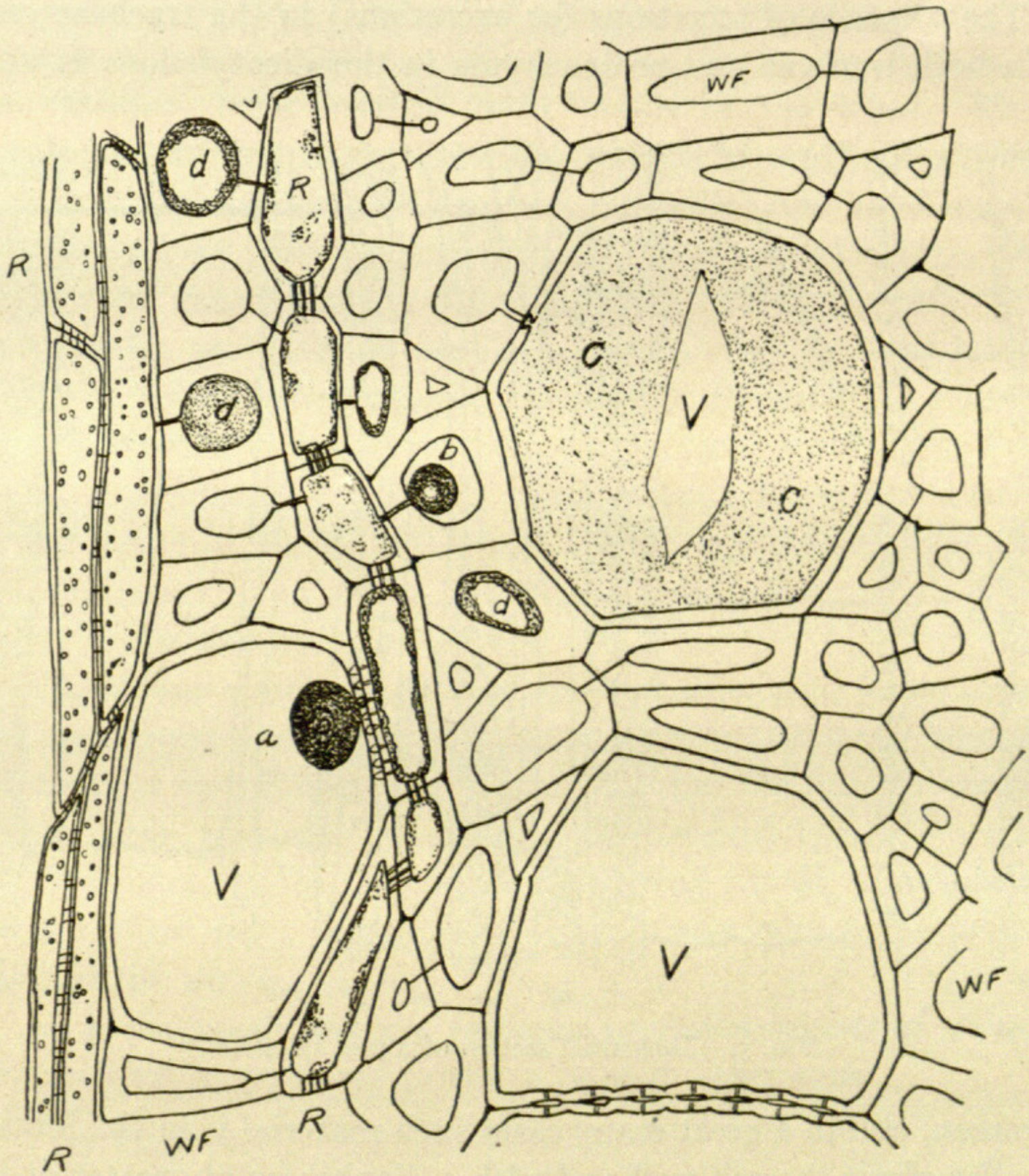

FIg. 4.-Transverse section of Nyssa sylvatica

in Pinus albicaulis. In Nyssa these masses occur in both the tracheae and wood prosenchyma and have their origin in the vertical strands of wood parenchyma $(W P)$ and in the rays $(R)$. Globules $(a, b)$ are shown emerging from the pits. The plates across the vessels are thin $(c)$, but those in the libriform fibers may be very thick $(d)$; in fact much of the fiber cavity may be completely 
filled except for occasional bubbles. Seen in transverse section a plate in a vessel appears as a thin imperforate membrane thickened in contact with the wall or with a rupture in the middle (fig. 4, c), presumably due to shrinkage. Exactly the same features charac'terize the resin masses in the tracheids of the gymnosperms.

The presence of secretions (or excretions) in the tracheae only or in both tracheae and prosenchyma in the dicotyledons is very

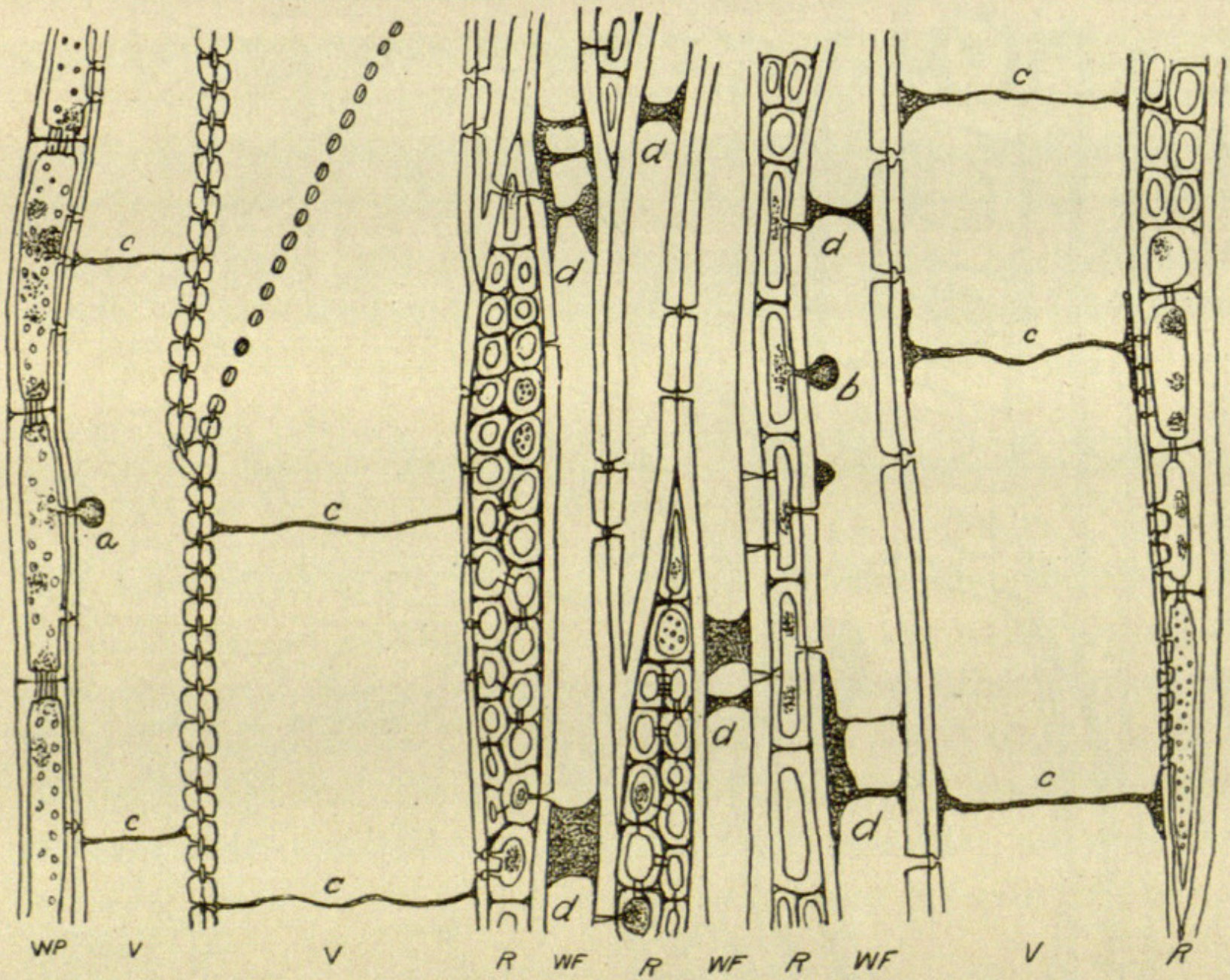

FIg. 5.-Tangential section of Nyssa sylvatica

common, and in a great many cases such material is in the form of a collar about the cell wall and with a diaphragm of greater or less thickness across the cavity. The writer believes that these various substances, although different in chemical composition, are alike in being excretions resulting from the metabolic activities of parenchyma cells, and represent waste materials. Although produced in varying amount under normal conditions, the greatest production occurs when the cells are about to cease their vital functions and become heartwood, or when a similar condition is produced abnor- 
mally, as in severe wounds. The low vitality of the ray and wood parenchyma at that stage may be considered responsible for the excessive amount of waste matter produced, some of which finds its way or is excreted into the cavities of the adjacent cells.

The parallel between the gymnosperms and angiosperms in the manner of their disposal of secreted or excreted products in the xylem extends further. Pinus, Picea, Larix, and Pseudotsuga, for example, have vertical resin canals in the wood. Similar canals are normal to the secondary woods of nearly all genera of Dipterocarpaceae and of Copaifera, Daniellia, Eperua, Kingiodendron, Oxystigma, Sindora, and Prioria of the Caesalpineoidae. Vertical resin canals arise traumatically in Abies, Sequoia, Tsuga heterophylla, and others; similarly canals may be produced by injury in Liquidambar, Styrax, Terminalia, Drimycarpus racemosa, etc. Resin canals in the medullary rays occur normally in Pinus, Picea, Pseudotsuga, and Larix; similar canals have been observed by the writer in representatives of II genera of Anacardiaceae and 2 of Araliaceae, ${ }^{2}$ and others have reported traumatic canals in both planes in Liquidambar and Styrax.

The writer concludes that resinous tracheids in gymnosperms find numerous parallels in the angiosperms, that they represent one form of reservoir for excretions, and that the form of the resin masses is in response to well known physical laws. No direct functional activity is attributed to the resin plates, although they are in certain ways analogous to tyloses and reduce the permeability of the wood.

As a diagnostic feature resinous tracheids appear of value in Pimus albicaulis and may prove to be so in other cases.

YaLe UnIVERsity

${ }^{2}$ Record, SAmuel J., Intercellular canals in dicotyledonous woods. Jour. Forestry $16: 429-44$ I. I9I8. 


\section{$2 \mathrm{BHL}$ Biodiversity Heritage Library}

Record, Samuel J. 1918. "Significance of Resinous Tracheids." Botanical gazette 66(1), 61-67. https://doi.org/10.1086/332303.

View This Item Online: https://www.biodiversitylibrary.org/item/109341

DOI: https://doi.org/10.1086/332303

Permalink: https://www.biodiversitylibrary.org/partpdf/224039

\section{Holding Institution}

Missouri Botanical Garden, Peter H. Raven Library

\section{Sponsored by}

Missouri Botanical Garden

\section{Copyright \& Reuse}

Copyright Status: Public domain. The BHL considers that this work is no longer under copyright protection.

This document was created from content at the Biodiversity Heritage Library, the world's largest open access digital library for biodiversity literature and archives. Visit BHL at https://www.biodiversitylibrary.org. 